\title{
Crevisto
}

\section{HISTÓRIA PÚBLICA E \\ ENSINO DE HISTÓRIA: \\ um olhar sobre o filme \\ no livro didático}

PUBLIC HISTORY AND HISTORY

TEACHING:

a look at the film in the didactic

book

HISTORIA PÚBLICA E HISTORIA

DE LA EDUCACIÓN:

a observar la película en

textbook

\section{Rodrigo de Almeida Ferreira ${ }^{1,2}$}

\section{RESUMO}

O artigo discute o ensino de História em diálogo com as perspectivas da história pública. Ao considerar o processo de ensino-aprendizagem sob o ângulo da mediação didática, elegemos o "filme com temática histórica" como mediador desse diálogo. A relação entre educação e história pública se acentua na interface com o cinema-história, pois a narrativa cinematográfica potencializa a divulgação, o compartilhamento e a ressignificação do conhecimento histórico circulante. Ao refletir sobre o filme na educação escolar, analisamos a inserção das narrativas fílmicas nos livros didáticos. Para tanto, discutimos como os filmes Xica da Silva e Chico Rei foram abordados nos livros didáticos circulantes entre 1978-2006, a partir do acervo LIVRES (FE/USP). Como resultado das análises, a reflexão proposta desenvolve a compreensão do ensino de história, mediado pelo filme, como prática de história pública.

\footnotetext{
${ }^{1}$ Doutor em Educação e Mestre em História pela UFMG. Graduado em História pela Pontifícia Universidade Católica de Minas Gerais (PUC Minas). Professor Adjunto na Faculdade de Educação da Universidade Federal Fluminense e do Programa de Mestrado ProfHistória (UFF). Membro da Rede Brasileira de História Pública (RBHP). E-mail: dealmeidarodrigo@gmail.com.

2 Endereço de contato do autor (por correio): Universidade Federal Fluminense, Faculdade de Educação/UFF. Campus Icaraí. CEP: 24220-900, Niterói, RJ, Brasil.
} 


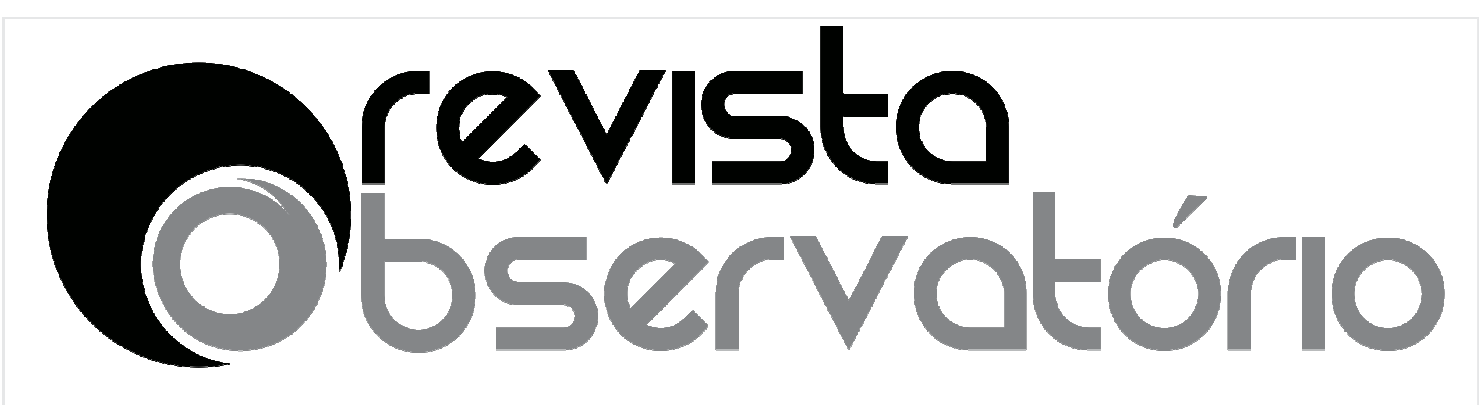

ISSN n² 2447-4266

Vol. 3, n. 2, Abril-Junho. 2017

DOI: http://dx.doi.org/10.20873/uft.2447-4266.2017v3n2p136

PALAVRAS-CHAVE: Educação; Ensino de História; História Pública; Filme;Livro Didático

\begin{abstract}
This article discusses history education in a dialogue with public history. Looking at the teaching-learning process from a didactic mediation angle, we chose "period piece film" as the mediator of this dialogue. The relation between education and public history is stronger at the interface with cinema-history, as film narrative enhances the dissemination, sharing and resignification of current history knowledge. Through reflecting on the effect film has on education, we analyzed how film narratives are inserted into text books. To this end, we analyzed how the movies Xica da Silva and Chico Rei were discussed in text books in circulation between 1978 and 2006, based on the LIVRES (FE/USP) collection.
\end{abstract}

KEYWORDS: Education; History Education; Public History; Film; Textbook

\title{
RESUMEN
}

El artículo discute La enseñanza de la Historia en diálogo com las perspectivas de la historia pública. Al considerar el proceso de enseñanza-aprendizaje desde elángulo de La mediación didáctica, elegimos la "película con temática histórica" como mediadora de ese diálogo. La relación entre educación e historia pública se acentua em la interfaz con el cine-historia, pues la narrativa cinematográfica potencializa La divulgación, el intercambio y La resignificación Del conocimiento histórico circulante. Al reflexionar sobre el cine en la educación escolar, analizamos La inserción de las narrativas fílmicas en los libros didácticos. Para eso, analizamos cómo se abordaronlas películas Xica da Silva y Chico Rei en los libros didácticos circulantes entre 1978-2006, a partir del acervo LIVRES (FE/USP). 


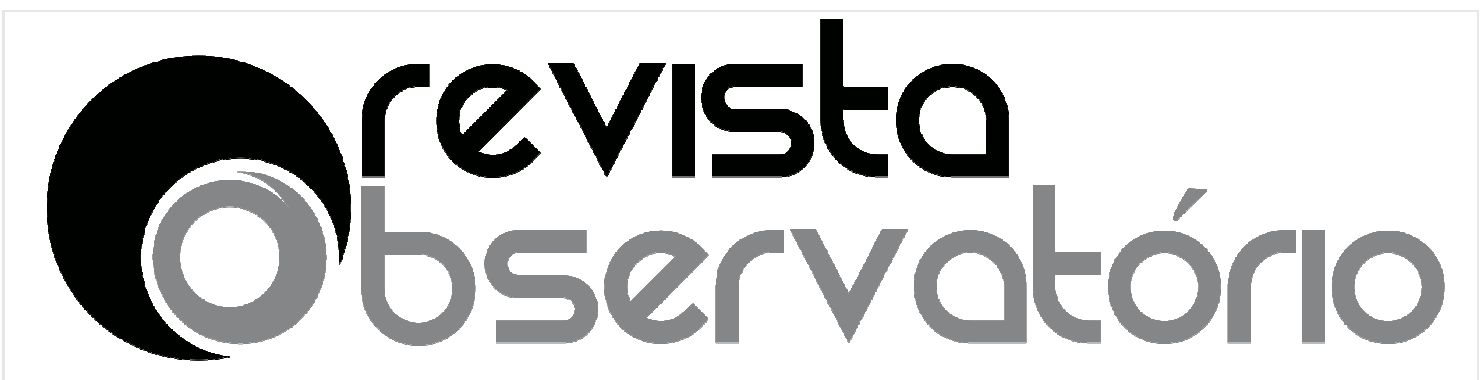

ISSN n² 2447-4266

Vol. 3, n. 2, Abril-Junho. 2017

DOI: http://dx.doi.org/10.20873/uft.2447-4266.2017v3n2p136

PALABRAS-CLAVE: Educación; Enseñanza de Historia; Historia Pública; Película; Libro Didáctico.

Recebido em: 22.01.2017. Aceito em: 26.03.2017. Publicado em: 01.04.2017. 


\section{Crevisto}

ISSN n² 2447-4266

Vol. 3, n. 2, Abril-Junho. 2017

DOI: http://dx.doi.org/10.20873/uft.2447-4266.2017v3n2p136

\section{Introdução}

Como pensar a relação entre a história pública e educação em História?Procuramos, a partir deste questionamento, dimensionar questões relacionadas aos filmes com temática histórica que permitem diálogos com a disciplina escolar, enfatizando os materiais de apoio aos alunos e professores. Nossas reflexões buscam dimensionar a inserção do uso do filme nas aulas de História por meio dos livros didáticos publicados a partir da década de 1970.

Diante das possibilidades reflexivas e dos limites impostos a um artigo, alguns esclarecimentos sobre escolhas e procedimentos são pertinentes. Certamente, consideramos relevante a discussão sobre história pública, todavia o viés conceitual não é o nosso caminho principal ${ }^{3}$, mas, sim, sua prática.Na mesma linha, não mergulharemos nas problematizações sobre as interseções entre história pública e cinema, embora não nos furtamos a abordagens cruciais a elas ${ }^{4}$.

A relação entre os filmes com temática histórica e o ensino da disciplina é pensada aqui na especificidade da sua incorporação nos materiais didáticos. Para isso, consideramos dois títulos produzidos no final da década de 1970, cuja temática central é a escravidão na América portuguesa, especificamente em Minas Gerais: Xica da Silva, dirigido por Cacá Diegues; e Chico Rei, dirigido por Walter Lima Júnior; lançados em 1976 e 1985, respectivamente. As análises destacam como os livros didáticos do período dos lançamentos fílmicos, e anos subsequentes, incorporaram a narrativa cinematográfica da história.

\footnotetext{
${ }^{3}$ Sobre história pública; cf.: ALMEIDA; MAUAD; SANTHIAGO (2016); ALMEIDA; ROVAI, (2011). Para periódicos que dedicaram dossiês ao tema; cf.: Revista Estudos Históricos, n.54, Rio de Janeiro, FGV, jul./dez. 2014; Revista Transversos, v.7, n.7, Rio de Janeiro, UERJ, set./2016; Revista Tempo e Argumento, v.8, n.19, Florianópolis, UFSC, set./dez. 2016.

${ }^{4}$ Uma abordagem mais detida sobre a temática, incluindo a perspectiva do livro didático nessa relação, foi realizada em pesquisa de doutoramento; cf.: FERREIRA, 2014.
} 


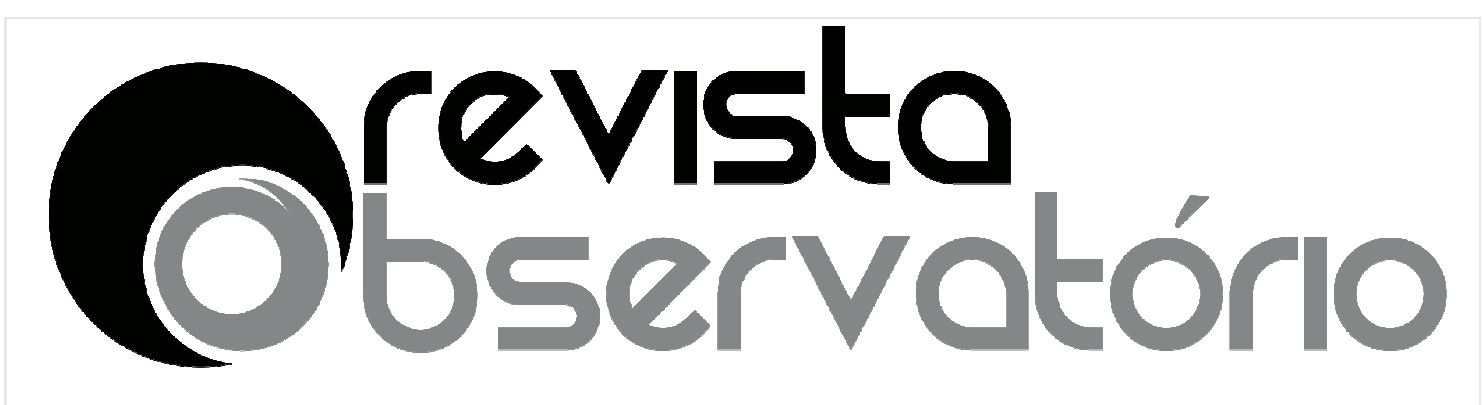

ISSN n² 2447-4266

Vol. 3, n. 2, Abril-Junho. 2017

DOI: http://dx.doi.org/10.20873/uft.2447-4266.2017v3n2p136

Os livros didáticos foram selecionados no recorte temporal de 1978 a 2006. O marco inicial considerou que possíveis reflexões sobre o filme de Diegues só seriam redigidas em 1977 e incorporadas no ano seguinte. Já o ano final (2006) considerou o período de dez anos após a publicação da atual Lei de Diretrizes e Base da Educação Nacional (LDB, Lei n. 9394/96), favorecendo a identificação de alterações e/ou permanências decorrentes da nova legislação educacional para o Ensino Básico.

Destacamos para a pesquisa o acervo da Biblioteca do Livro Didático da Faculdade de Educação da Universidade de São Paulo (LIVRES-FE/USP). No primeiro momento, foram levantados 1.248 (mil duzentos e quarenta e oito) títulos. A partir daí, foram estabelecidos três intervalos temporais: $\left.1^{\circ}\right){ }^{1978-}$ 1985; 20) 1986-1996; $3^{\circ}$ ) 1997-2006; que abarcaram livros do ensino fundamental e médio $\left(1^{\circ}\right.$ e $2^{\circ}$ graus, como denominado até a promulgação da atual LDB). Dentro desses parâmetros de temporalidade e níveis de ensino, foram analisados os materiais que traziam referências aos filmes supracitados, totalizando314 (trezentos e quatorze) títulos/edições, assim distribuídos: 83 (oitenta e três) livros didáticos para o $1^{\circ}$ período; 113 (cento e treze) para o $2^{\circ}$ período; e 118 (cento e dezoito) para o $3^{\circ}$ período.

Problematizamos a prática do ensino de história na interface com o uso do filme na sala de aula, linguagem que se popularizou na escola em meados da década de 1980. Assumimos como parâmetro o livro didático, outra importante ferramenta para o cotidiano escolar. É nesse diálogo que propomos pensar a história pública e o ensino de História. 


\section{Crevisto}

ISSN n² 2447-4266

Vol. 3, n. 2, Abril-Junho. 2017

DOI: http://dx.doi.org/10.20873/uft.2447-4266.2017v3n2p136

\section{História Pública: a indefinição de uma prática}

Questões sobre a História Pública têm apresentado instigantes reflexões desde que o debate sistematizado sobre o tema tem se estabelecido no Brasil, inclusive com a organização de interessados na Rede Brasileira de História Pública (RBHP). Nos três simpósios internacionais ocorridos no país (Universidade de São Paulo/São Paulo, 2012; Universidade Federal Fluminense/Niterói, 2014; Universidade Regional do Cariri/Cariri, 2016), constatamos a ampliação do alcance, assim como a permanência de dúvidas quanto a definição do termo.

A preocupação com a delimitação conceitual da história pública não é exclusividade brasileira, sendo identificada também em países com maior tradição no campo, como Estados Unidos e Inglaterra. A esse respeito reiteramos nosso alinhamento à percepção de que a história pública continua a ser História; a mais antiga de todas as histórias, como pondera Jill Liddington (2011:34). De fato, não se trata de inédita metodologia de pesquisa ou de tratamento de fontes.

Mas, então, o que justifica a organização de eventos com a participação de acadêmicos e não-acadêmicos, publicações e dossiês temáticos sobre o assunto? Destacamos, entre os elementos que balizam a ideia de história pública: ampliação dos públicos; divulgação; produção compartilhada; circulação do conhecimento histórico.

A dimensão pública da História, desse modo, é uma preocupação central, ainda que tais balizas também possam ser reconhecidas nas pesquisas acadêmicas. Podemos relacionar o crescimento da importância comunicacional do conhecimento histórico ao contexto de renovações das linguagens e 


\section{Qrevisto}

ISSN n² 2447-4266

Vol. 3, n. 2, Abril-Junho. 2017

DOI: http://dx.doi.org/10.20873/uft.2447-4266.2017v3n2p136

suportes de arquivamento e acesso, desde a década de 1970 - sobremaneira ao audiovisual e a popularização da internet e das redes sociais.

Outra dimensão reside no reconhecimento de que o saber histórico é dialógico, circulante. A produção em história pública contribui, assim, para problematizar a concepção corrente de que a "História verdadeira" é a produzida nas Faculdades de História. Trata-se de reconhecer outros campos de produção e significação do conhecimento histórico, como a literatura, o cinema, a educação. Um esforço, pois, para ouvir e trabalhar conjuntamente com outras áreas de saberes e dialogar com múltiplas formas de comunicar os resultados. Algo que necessita deslocamentos, sem, contudo, negar ou desqualificar o ofício dos historiadores ou outros profissionais envolvidos na pesquisa, produção e comunicação. Confluímos ao entendimento da história pública como área de estudo e ação no entrecruzamento da:

história feita para o público (que prioriza a ampliação de audiências); a história feita com o público (uma história colaborativa, na qual a ideia de "autoridade compartilhada" é central); a história feita pelo público (que incorpora formas não institucionais de história e memória); e história e público (que abarcaria a reflexividade e a autorreflexividade do campo). (SANTHIAGO, 2016, p. 28)

Para Liddington (2011:50), o ponto central é "menos sobre quem ou o que, e muito mais sobre como. Nem tanto um substantivo, principalmente um verbo". Ou seja, parece mais produtivo pensar o processo da história pública na relação cotidiana de produção do significado histórico. Essas observações preliminares, portanto, ajudam a compreender como estamos a pensá-la em relação com o ensino da disciplina histórica, especialmente pela linguagem fílmica e sua apropriação pelos livros didáticos. 


\section{Gevisto
Observatório}

ISSN n² 2447-4266

Vol. 3, n. 2, Abril-Junho. 2017

DOI: http://dx.doi.org/10.20873/uft.2447-4266.2017v3n2p136

\section{A sala de aula: lugar por excelência da História Pública}

"Eu sempre fiz história pública, só não sabia o nome" (SANTHIAGO, 2016, p. 25).Seja nos referidos simpósios (USP, UFF, URCA), ou em outros eventos que colocam o tema, essa tem sido uma expressão recorrente entre professores após entrarem em contato com os debates. O que pode ter favorecido essa percepção?

Como hipótese, inferimos que o docente identifica os referidos elementos balizadores da história pública em sua prática profissional, na dinâmica da educação do conhecimento histórico com os alunos. Na educação histórica escolar se opera a divulgação, a ampliação dos públicos e a circulação do conhecimento histórico com bastante intensidade e amplitude. A seleção do tema, a apresentação do conteúdo, o desenvolvimento da reflexão, faz da aula um momento especial em que estudantes entram em contato com o passado/presente e se repensam enquanto sociedade.

Sem adentrar ao complexo campo do currículo, observamos que a organização escolar dos conteúdos integram escolhas políticas, econômicas, sociais, assim como a própria organização da escola, seu tempo, sua estrutura. A seleção de conteúdos elege um saber a ser ensinado e outro que, nem sempre por razões explícitas, é silenciado. Entretanto, sabemos que a sala de aula desenvolve dinâmicas próprias. Mesmo limitada por diretrizes e processos avaliativos externos, é recorrente enfatizar, mais ou menos, um determinado assunto ou mesmo abordar temas não obrigatórios, seja por escolha do docente ou por reivindicação do alunado.

Ao compreendermos a História enquanto processo, ampliamos suas possibilidades no ensino. Lembramos a lição de Lucien Febvre de que a reflexão histórica se volta aos acontecimentos do passado a partir do presente. Desse 


\section{Oevisto}

ISSN n² 2447-4266

Vol. 3, n. 2, Abril-Junho. 2017

DOI: http://dx.doi.org/10.20873/uft.2447-4266.2017v3n2p136

modo, o ensino da disciplina frequentemente transita por uma "ponte temporal", na qual passado e presente dialogam. Uma aula sobre o processo de abolição da escravidão, por exemplo,está imbricada à importância da relação contemporânea entre o Estado e o racismo, do estudo das culturas afrobrasileiras e indígenas, à falácia da democracia racial, às políticas de cotas raciais.

A história ensinada no século XXI tende a romper o modelo do professor detentor do saber a ser transmitido ao estudante como "educação bancária" (FREIRE, 1981).A dinâmica na sala de aula faz do processo ensino-aprendizagem um momento rico e plural. As trocas se fazem entre os saberes: profissional; acadêmico; estudantil(atrelado contexto social); histórico circulante (literatura, filmes, novelas, museus etc). Enfim, nessa vivência aparecem os locais de experiência do professor, do aluno, da comunidade escolar, da sociedade. A sala de aula, portanto, se estabelece como um espaço para a história pública.

Considerando a "educação através de saberes" (CHERVEL, 1990; MONTEIRO, 2013), a complexidade do ensino-aprendizagem exige do professor domínio teórico e metodológico da sua área para garantir a experiência da aprendizagem. Trata-se d'o que ensinar, e do como ensinar, em uma operação definida por Monteiro como mediação didática/cultural:

Abordamos esse processo como 'relação' pois é constituído com base nas experiências vivenciadas por historiadores e professores, e porque produz experiências no seu auditório [estudantes]. Daí afirmarmos que esse processo é mediação cultural ao se desenvolver no currículo entendido como 'lugar de fronteira', no qual sentidos são produzidos com base nas articulações entre enunciados proferidos por docentes e alunos, e apresentados em livros e outros materiais didáticos. (MONTEIRO, 2013, p. 31) 


\section{Orevisto}

ISSN n² 2447-4266

Vol. 3, n. 2, Abril-Junho. 2017

DOI: http://dx.doi.org/10.20873/uft.2447-4266.2017v3n2p136

Não obstante as variadas possibilidades metodológicas para 0 desenvolvimento da aula de História, ainda permanecem resquícios do momento da institucionalização da escola, no século XIX. Nesta escola, o professor de História,assim como nas demais disciplinas, deveria ser capaz de sistematizar o conhecimento elaborado nas universidades em linguagem acessível para a educação básica dos alunos.Definido como "transposição didática"(CHEVALLARD, 1995), tecemos uma breve reflexão decorrente deste procedimento pedagógico para pensar seu impacto no entendimento na relação sala de aula/história pública.

A proposição de Chevallard teve grande aceitação no campo educacional. Do mesmo modo, convive com revisões e contestações, por exemplo, a crítica ao excessivo espaço do saber acadêmico na concepção da transposição didática (CHERVEL, 1990), o que termina por considerar a universidade, a escola e a sociedade como esferas sujeitas a sobreposição. Alinhamo-nos às críticas de que muitos saberes práticos, ou mesmo nãoescolar, se inserem primeiro na sociedade e na escola, para então serem sistematizados no ensino superior. Ademais, se o professor adepto da transposição didática considerar somente o deslocamento do saber acadêmico para o público da educação básica, ele pode incorrer em demasiada simplificação, reducionismo, anacronismo e mesmo levar ao erro de interpretação histórica.

Os professores que atuam na educação básica não estão ali produzindo conhecimento novo a ser validado pelos seus pares com base na utilização correta e adequada de referenciais teóricometodológicos. No contexto escolar, realizam um trabalho de articulação entre saberes oriundos da produção científica e saberes dos alunos, seus próprios saberes e aqueles que circulam na sociedade, de modo a tornar possível sua compreensão, ou seja, uma reelaboração de forma que os sentidos atribuídos pelos alunos - e 


\section{Crevisto}

ISSN n² 2447-4266

Vol. 3, n. 2, Abril-Junho. 2017

DOI: http://dx.doi.org/10.20873/uft.2447-4266.2017v3n2p136

que dependem dos sentidos atribuídos pelos professores ao saber ensinado - se aproximem dos significados validados. (MONTEIRO, 2013, p. 31)

A transposição didática nos coloca, ainda, o problema da hierarquização do saber. Ao considerar a produção realizada nas faculdades de História a fonte legítima (ou a mais correta) desse conhecimento, que deve ser operada por procedimentos didáticos de transposição voltada à educação básica, implica em reconhecer a gênese da hierarquia entre saber acadêmico versus saber escolar e/ou popular.

Consequentemente, isso implica na desvalorização dos saberes locais, tradições populares, memórias e outras abordagens da História não operadas por historiadores de ofício. Recordamos que a história pública propõe uma prática contrária, ou seja, busca valorizar outros saberes referentes ao conhecimento histórico, ainda que não tenham sido realizados exclusivamente por um historiador.

A produção realizada em variadas áreas,seja individualmente ou em parceria, deve ser problematizada pela promoção do diálogo entre esses saberes; não pelo rebaixamento, pela desconsideração, pela anulação. Reconhecer esses significados é ompreender o modus operandi de cada área profissional; sem que o historiador se anule ou seja ameaçado. As memórias, as tradições, a subjetividade relativa ao passado/presente também constroem significados históricos; mesmo que não tenham sido processados pela metodologia acadêmica ou que contradigam pesquisas mais elaboradas realizadas pelos historiadores. Desconsiderá-los em nome de uma tradição de autoridade termina por prejudicar a multiplicidade de interpretações e a polifonia inerentes à sociedade. 


\section{Orevisto}

ISSN n² 2447-4266

Vol. 3, n. 2, Abril-Junho. 2017

DOI: http://dx.doi.org/10.20873/uft.2447-4266.2017v3n2p136

A sala de aula como prática de história pública contribui, portanto, para a ruptura de posições herméticas relativas à História. E, sobremaneira, desenvolve discussões e promove a circularidade do conhecimento histórico considerando múltiplas possibilidades. Pensar e produzir no viés inter/transdisciplinar favorece, em certa medida, diminuição da sensação de afastamento entre universidade e sociedade, como reclamam diversos grupos sociais - inclusive professores do ensino básico. Quer dizer, não manter os portões universitários como barreiras, mas área de livre circulação para a população. É saudável uma sociedade onde universidade e população se reconheçam com menos estranhamento.

Em última instância, o escalonamento entre saber erudito versus saber popular reitera o preconceito de que o bacharel é um profissional melhor capacitado do que o licenciado. Ainda que dificilmente admitida, tal superposição é facilmente sentida nos corredores das faculdades de História, nas escolas e na sociedade. Ela alimenta a incômoda percepção de que o professor de História, embora tenha cursado uma faculdade, em muitos casos se especializado e pós-graduado, não se/seja reconhece/reconhecido como historiador ou permanece a crença de que seu conhecimento é inferior ao do historiador-pesquisador.

Não é nessa distância que acreditamos. Entendemos a escola como espaço por excelência da construção do diálogo, do respeito às diferenças, do convencimento por argumentos, evidências, razoabilidade. Uma construção dialógica entre sujeitos, objetos e fontes, nas dimensões passado, presente e futuro:

Neste sentido, o Ensino de História, tal como a História Pública, pode ser pensado como espaço/tempo de fronteira (...). Nas fronteiras do ensino de História, a comunidade escolar se movimenta em Revista Observatório, Palmas, v. 3, n. 2, p. 136-171, abr./jun. 2017 


\section{Crevisto}

ISSN n² 2447-4266

Vol. 3, n. 2, Abril-Junho. 2017

DOI: http://dx.doi.org/10.20873/uft.2447-4266.2017v3n2p136

temporalidades disjuntivas, entre significações de passado e presente, entre conhecimentos historiográficos e memórias locais, entre histórias de vida e significações coletivas, enfim, rompendo polarizações e produzindo um movimento que vivencia a diferença, habitando o entrelugar. (ANDRADE; ANDRADE, 2016, p. 183)

A recorrente identificação dos professores como praticantes (ainda que inconscientes) da história pública no exercício da sua profissão colabora, também, para redimensionar o locus da História. Não é incomum associar a história pública a uma história informal, realizada por não historiadores. Ou seja, fora da academia e da própria escola.

Entretanto, não é bem assim. Espaços tradicionais de saber, como as universidades e a escola, permanecem essenciais para a qualificação do conhecimento histórico. A história pública valoriza a multiplicidade de significados produzidos em narrativas veiculadas em distintos suportes acadêmicos, cinematográficos, museológicos, musicais etc. E entende como profícua a ampla circulação dessas narrativas, pois os diálogos - que pressupõem reafirmações, complementaridade, contradições, ineditismos (re)constroem e (res)significam o conhecimento histórico. A historiografia mantém sua referência, assim como as memórias, as tradições populares, as elaborações da história no âmbito escolar também têm seus valores reconhecidos. Desde que problematizadas, essa polifonia traz contribuições à compreensão do passado/presente.

\section{O cinema como história pública}

Os modos de circular o conhecimento histórico são variados. Revistas têm feito esse papel desde o final do século XIX. Thaís Fonseca observa que,no século $X X$,houve a tendência de criação de revistas científicas pelos próprios centros produtores de pesquisa. Por outro lado, a expansão do mercado Revista Observatório, Palmas, v. 3, n. 2, p. 136-171, abr./jun. 2017 


\section{Crevisto}

ISSN n² 2447-4266

Vol. 3, n. 2, Abril-Junho. 2017

DOI: http://dx.doi.org/10.20873/uft.2447-4266.2017v3n2p136

editorial permitiu que publicações mais populares ocupassem bancas de revistas.Ainda assim, permaneceram ruídos na comunicação entre a produção acadêmica e o grande público, pois a tentativa de publicar resultados de teses não era bem vista até meados dos anos 1980. Segundo a autora, a mudança ocorre com a maior preocupação dos historiadores na divulgação de seus trabalhos, estimulados pelos europeus que ocuparam

espaços e meios de comunicação fora da academia, na televisão, em jornais e revistas de grande circulação. Não se pode deixar de mencionar, também, a estreita relação dessa mudança com os movimentos de renovação na historiografia brasileira, responsáveis pela expansão da pesquisa para novas abordagens e novos horizontes temáticos, muitos deles bastantes atraentes aos olhos do público leigo. (FONSECA, 2016, p. 186)

Renovações metodológicas para a educação em História têm levado a diversificação de fontes no cotidiano da sala de aula. Revistas, jornais, iconografia, música, filmes, enredos carnavalescos, jogos eletrônicos, conteúdos da internet, por exemplo, fazem parte do como ensinar- e aprender - História. Dessas fontes, vejamos como os filmes têm sido incorporados na didática da disciplina, especialmente na interface com a história pública.

Inegavelmente, o cinema se tornou referência cultural no século XX. Desde seu invento, diretores buscaram inspiração na História. O inverso, contudo, não seguiu a mesma celeridade, haja vista a resistência entre historiadores em considerar o produto cinematográfico como fonte de pesquisa.

Para o professorado do ensino básico, a dificuldade em incorporar o filme no seu trabalho ia além das questões teórico-metodológicas que afligiam 


\section{Oevisto}

ISSN n² 2447-4266

Vol. 3, n. 2, Abril-Junho. 2017

DOI: http://dx.doi.org/10.20873/uft.2447-4266.2017v3n2p136

os pesquisadores em sua relação com as fontes ${ }^{5}$. Ela era concreta, material, diante da quase nulidade de escolas em condições de projetar um filme. $E_{\text {, }}$ ainda que houvesse o equipamento necessário, seriam reais as dificuldades para obtenção dos rolos fílmicos e os custos da operação.

No início da década de 1980, as escolas passaram a receber o cinema em suas dependências graças aos aparelhos reprodutores de fitas cassete. No Brasil, administrações públicas passaram investir no aparelhamento das escolas com televisões, vídeos cassetes e videotecas, bem como na capacitação dos professores.

A popularização dos aparelhos domésticos para assistir aos filmes foi acompanhada pelo aumento das reflexões do uso educativo dos filmes. $E$ isso não é uma coincidência ${ }^{6}$. Os Parâmetros Curriculares Nacionais para o Ensino de História (PCNs), publicados em 1997-98, como referência de adequação do ensino a nova LDB, enfatizavam o filme como destacada fonte para o trabalho a ser desenvolvido em sala de aula, por exemplo.

O potencial do cinema para a história tem sido bastante pesquisado. Como reflexo, nos dias atuais, nos cursos de licenciatura, não é tão complicado

\footnotetext{
${ }^{5}$ O debate se intensifica a partir da década de 1960, com destaque para propulsor o artigo $O$ Filme: uma contra-análise da sociedade?,publicado por Marc Ferro na coleção História: novos objetos, novos problemas, novos métodos, organizada por Jacques Le Goff e Pierre Nora, em 1974.

${ }^{6}$ A discussão do cinema educativo acompanha o desenvolvimento do cinema, especialmente nas décadas de 1920-30, quando A União Cinematográfica Educativa (LUCE), criada na Itália Fascista (1924), inspirou ações em outros países. No Brasil, em 1931, dois livros reverberaram o debate que intelectuais e educadores desenvolviam por meio da imprensa, revistas e projetos de políticos: Cinema e Educação, de Jonathas Serrano, em coautoria com Francisco Venâncio Filho; e Cinema contra cinema, de Joaquim Canuto de Almeida. Naquele contexto, o governo Vargas criou o Instituto Nacional de Cinema Educativo (INCE, 1937), a mais longeva experiência nesse sentido. Não obstante, a popularização da exibição dos filmes em sala de aula, a partir da década de 1980, compreensivamente fez com que a prática didática estimulasse reflexões teórico-metodológicas sobre ela. Para o cinema educativo, cf.: MORETTIN, 1995; 2013; ROSA, 2013; SÁ, 1967; SIMIS, 2015.
} 


\section{Orevisto}

ISSN n² 2447-4266

Vol. 3, n. 2, Abril-Junho. 2017

DOI: http://dx.doi.org/10.20873/uft.2447-4266.2017v3n2p136

encontrar disciplinas sobre a relação cinema-história-educação. Todavia, como avaliar esse potencial enquanto história pública? Em que medida se estabelece essa interface?

De início observamos que a produção cinematográfica é dependente de saberes e compartilhamentos. A sétima arte requer o trabalho em equipe, considerando as especificidades de cada profissional: diretor, roteirista, atores, figurinistas, cenógrafos, câmera, fotógrafos etc. É, portanto, um exemplo de trabalho de grupo,liderado geralmente pelo diretor e organizado mais horizontalmente para atingir o objetivo. Nesse sentido, há um paralelo em o modus operandi do cinema e um pilar da historia pública: o compartilhamento.

Conforme salientamos, a História sempre foi acionada por roteiristas e diretores. A vida cotidiana, as memórias, as histórias subterrâneas, outras interpretações de determinados acontecimentos frequentemente despertam a curiosidade e chegam a grande tela, afinal:

Os realizadores de cinema - que também formam parte da sociedade - se "alimentam" desta para extrair temas para seus novos filmes e com tais influenciam - sendo, por sua vez, influenciados pelo contexto - e conformam, de algum modo, a sociedade. (LERA, 2007, p. 30 tradução livre.)

Esse movimento reflete o enlace da História para a identidade e organização da sociedade. $O$ interesse comercial é condicionante para a filmagem, mas não se pode negligenciar que, muitas vezes, o filme é realizado na busca por respostas e contradições do presente, pela discordância às narrativas construídas, para registrar algo que se valoriza e/ou corre o risco de desparecer.

Segundo Caparrós Lera, esse movimento não é unidirecional,centrado no realizador do filme. Mas,também,das pessoas que acessam aquela narrativa 


\section{Rrevisto Observatório}

cinematográfica da história. Esse processo coloca em circulação os conhecimentos históricos em variadas narrativas e formatos, que podem passar da produção acadêmica, memórias sociais, individuais, festejos locais, arquitetura, culinária, fotografias e até outros filmes. Enfim, variados registros são mobilizados, sem haver,necessariamente, uma hierarquia entre eles.

No filme Chico Rei, por exemplo, as principais fontes inspiradoras para a construção do roteiro e guia do diretor são mencionadas em cartelas ${ }^{7}$. Duas delas aparecem logo no início do filme: a primeira explica a dinâmica do comércio de homens escravizados na África para o Brasil; e a segunda indica que o argumento foi baseado no roteiro de "Mário Prata, na tradição oral mineira, na poesia de Cecília Meireles e na memória do negro brasileiro".Uma terceira cartela é exibida no final com as "fontes essenciais de consulta"

O filme com temática histórica, mais do que colocar em circulação narrativas existentes, pode contribui para (re)significá-las. Por vezes, são temas ainda inéditos no tratamento acadêmico. E mesmo quando o filme reitera versões já conhecidas, ele pode favorecer o levantamento de questões. Por isso, mesmo se contradizer a historiografia mais recente, percebemos aí um bom momento para levantar questões sobre a História, ao invés de apenas indicar os equívocos da representação fílmica.

O uso do filme para a discussão e compreensão dos processos históricos, entretanto, não é tarefa simples, haja vista a característica do cinema que traz

\footnotetext{
${ }^{7}$ Recurso que exibe informações escritas na tela. Recorrente durante o cinema silencioso como mediador da narrativa, sua persistência mantém a intenção inicial de informar o espectador, sendo frequentes no início de filmes com temática histórica para contextualizar temporal e espacialmente o enredo; e no final como explicação dos desdobramentos da trama e dos personagens representados.

${ }^{8} \mathrm{Na}$ ordem: História da escravidão, de Maurílio Gouveia; Os africanos no Brasil, de Nina Rodrigues; $O$ escravismo colonial, de Jacob Gorender; $O$ negro na civilização brasileira, de Arthur Ramos; As religiões africanas no Brasil, de Roger Bastide; Chico Rei, de Agripa Vasconcelos; Os condenados da terra, de Frantz Fanon.
} 


\section{Crevisto}

ISSN n² 2447-4266

Vol. 3, n. 2, Abril-Junho. 2017

DOI: http://dx.doi.org/10.20873/uft.2447-4266.2017v3n2p136

em si uma gama de elementos ideológicos, do campo estético, da cultura, da história, do lazer. Marcos Napolitano (2005) ressalva que há uma tendência em polarizar o cinema-história ou pelo viés realista ou subjetivista. Neste, os filmes são criticados pela subjetividade inerente a linguagem fílmica. Naquele, os filmes são encarados como parâmetros da recriação histórica, como uma representação parcial do passado, levando os elementos de reconstituição de época, por exemplo, a terem maior relevância do que a reflexão sobre o processo histórico.

Concordamos com Napolitano que cerrar posição em uma dessas trincheiras restringe o uso educativo do cinema-história. Um caminho possível para ultrapassar a barreira é explorar a diversidade da linguagem fílmica como fonte e objeto para o conhecimento histórico, analisando seus elementos narrativos e o conteúdo de História a partir das representações sócio-históricas produzidas.

Com todo o risco de ruídos, são possíveis os diálogos entre o cinema e a História e a educação do conhecimento histórico. Respeitando os limites da comparação, reconhecemos um paralelo entre a construção fílmica e o planejamento de uma aula. Há semelhanças em ambos os processos quanto a escolha do tema, a elaboração das hipóteses, a pesquisa e a seleção de fontes, ao desenvolvimento do argumento. Etapas que são articuladas e resultam em uma narrativa sobre a história no suporte do filme e na prática ensinoaprendizagem na escola.

Os filmes com temática histórica, dada sua dimensão de história pública, são pertinentes para a educação mesmo fora do ambiente escolar. É certo que, neste caso, a dinâmica e o processo são outros, pois dependem da articulação de saberes pessoais do espectador e sua disposição para refletir a partir dos 


\title{
Crevisto
}

ISSN n² 2447-4266

Vol. 3, n. 2, Abril-Junho. 2017

DOI: http://dx.doi.org/10.20873/uft.2447-4266.2017v3n2p136

estímulos fílmicos. Mas é na sala de aula, onde o filme é adotado como uma prática educativa, mediante recortes e objetivos específicos, que nos interessa neste momento:como os filmes entraram nas aulas de história?

\section{O cinema na sala de aula: o suporte livros didáticos: Estudo dos casos Xica da Silva e Chico Rei}

O cinema entrou na pesquisa histórica a partir década de 1960, mas na sala de aula sua inserção ocorreu cerca de 20 anos depois, tanto pela exibição nas modernas salas equipadas com videocassete como pelos livros didáticos. É inegável a centralidade do livro didático na escolarização básica, não obstante a difusão de outros recursos pedagógicos. Essas "ferramentas pedagógicas", além do conteúdo técnico, elegem elementos a serem transmitidos às gerações mais jovens, reflexo de seleções culturais repassadas por esses meios de comunicação cuja eficácia está na importância de suas formas de difusão (CHOPPIN, 2004). O livro didático, portanto, ultrapassa a educação de conteúdos curriculares.

\begin{abstract}
A compreensão do livro como um espaço de relações não permite que se fale sobre "o texto" em abstrato, como existente fora dos objetos escritos que permitem uma leitura, mas de um objeto que resulta de um conjunto de elementos materiais que compõem o livro [...] a produção textual também sofre a ação de um processo complexo das relações de poder da realidade sócio-histórica, que limitam, restringem e condicionam esta produção". (GASPARELLO, 2004, p. 23)
\end{abstract}

A complexidade dos livros didáticos, cujos interesses envolvem projetos políticos, sociais e econômicos, o tornou para alguns profissionais um elemento sacralizado; para outros educadores, um mal necessário ou a ser evitado.No campo da História, o incômodo maior com esses materiais recai na permanência do ensino memorialista e de baixa criticidade do processo 


\section{Orevisto}

ISSN n² 2447-4266

Vol. 3, n. 2, Abril-Junho. 2017

DOI: http://dx.doi.org/10.20873/uft.2447-4266.2017v3n2p136

histórico. A História organizada com ênfase na cronologia, nos acontecimentos de natureza política e na heroificação de personagens é refletida na concepção de ensino e avaliação conhecida como "pedagogia do exame" (LUCKESI, 2003).

Os estudos sobre o livro didático no ensino de História têm crescido consideravelmente desde o trabalho pioneiro de Bittencourt (1993): cerca de 50 pesquisas naquele período para aproximadamente 800 realizadas entre 2001-11 (MUNAKATA, 2012). Embora o material continue a ser referência para 0 estudante em seu cotidiano escolar, a criticidade do saber/fazer docente tem qualificado o uso do livro didático. Mesmo que muitos títulos ainda deixem a desejar, é perceptível a modernização na produção editorial, transformação em sua linguagem e adequação às renovadas práticas educacionais. Exemplificam a tentativa de reescrita desses manuais escolares ao contexto do século XXI: a organização por eixos temáticos, a valorização das fontes para análise do processo histórico, a ênfase na significação histórica e desenvolvimento da crítica, os diálogos com a produção cultural(cinema, música, arte, quadrinhos, literatura), a incorporação dos recursos da internet, a inter $\mathrm{e}$ transdisciplinaridade.

Ressalvamos a distância entre a forma como as referências ao filme são apresentadas nos livros (comentários, análises, sugestões de trabalho etc) e a incorporação daquele filme como trabalho didático. Essa avaliação depende de pesquisas sobre a prática docente/discente e o uso do filme nesse processo. Algo não só pertinente como necessário e que contribuirá para os estudos das práticas e do uso do livro didático no ensino da disciplina. Limitamo-nos, todavia, à análise do material existente no acervo LIVRES-FE/USP que circulou nas escolas entre 1978 e 2006. 


\section{Qrevisto}

ISSN n² 2447-4266

Vol. 3, n. 2, Abril-Junho. 2017

DOI: http://dx.doi.org/10.20873/uft.2447-4266.2017v3n2p136

O foco da análise recaiu em dois filmes ${ }^{9}$. Xica da Silva, que se tornou um grande sucesso comercial do cinema brasileiro. O filme traz a trajetória da escrava Francisca da Silva, por quem se apaixonou João Fernandes de Oliveira, o Contratador dos Diamantes, ao chegar a sede do Distrito Diamantino (arraial do Tejuco, atual Diamantina) para explorar os negócios das pedras preciosas. Xica foi alforriada durante o romance, que gerou uma dezena de filhos (descendência não abordada no filme). A relação só foi interrompida com a convocação real para o retorno do Contratador a Portugal, após tumultos na administração. Durante as quase duas décadas juntos, contudo, a união escandalizou a sociedade colonial pela exposição da relação inter-racial entre uma das mais elevadas autoridades portuguesas com uma ex-escrava e a conduta pouco reservada de Chica. O filme gerou polêmicas, especialmente entre setores dos movimentos negros e feministas que acusaram o diretor de explorar uma imagem da mulher negra como objeto sexual, reforçando negativamente estereótipos na História do país.

O outro filme é Chico Rei: uma história de liberdade, que possui uma conturbada história de produção. Contemplado na inédita linha de crédito da Embrafilme Filmes Históricos (1977), foi planejado para ser uma série televisiva com 13 episódios, mais um longa-metragem com o material filmado.Os problemas começaram com a ruptura da parceria com os produtores alemães (Provobis). Falta de recursos e batalhas judiciais quase impediram o lançamento do filme, ocorrido somente em 1985.

O filme de Walter Lima Júnior procurou reconstruir a trajetória mítica de Galanga, nobre africano escravizado pelos portugueses e transportado para o Brasil. Rebatizado como Chico, terminou em Vila Rica (atual Ouro Preto), onde

\footnotetext{
${ }^{9}$ Sobre os filmes em sua interface como história pública, cf.: FERREIRA, 2014.

Revista Observatório, Palmas, v. 3, n. 2, p. 136-171, abr./jun. 2017
} 


\section{Crevisto}

ISSN n² 2447-4266

Vol. 3, n. 2, Abril-Junho. 2017

DOI: http://dx.doi.org/10.20873/uft.2447-4266.2017v3n2p136

foi alforriado pelo seu proprietário. Livre, continuou a trabalhar na mina do seu ex-senhor, revertendo o ouro extraído, somado ao extravio feito por outros escravos, para alforriaros cativos. Com a ajuda da irmandade do Rosário dos Homens Pretos, comprou a Mina da Encardideira, intensificando a libertação de escravos. A lembrança do seu passado e sua ascendência na sociabilidade entre os negros, lhe valeram a alcunha de Chico Rei.

Historicamente, os dois filmes se passam no mesmo contexto: o século XVIII. Em especial, trazem como protagonistas personagens negros, apresentados como resistência à escravidão, encontrando formas não apenas de viver nas condições adversas como tentar se beneficiar delas. Outras questões emergem desses títulos: as relações de trabalho, de poder, de corrupção, de preconceito, de religiosidade, de sexo. Forma-se, assim, a tessitura de aspectos que permitem o debate sobre o processo histórico e social do período da América Portuguesa. Ressaltamos que, no momento do lançamento de ambos os filmes, a historiografia brasileira se abria às renovações metodológicas da história sociocultural,aplicando novas abordagens sobre muitos desses temas.

As construções narrativas sobre Chica da Silva e Chico Rei também percorrem caminhos similares. Ambas são correntes na tradição popular e permaneceram como expressão cultural. Antes de chegarem ao cinema, foram temas da literatura, poesia e carnaval - com muitas coincidências.

No final do século XIX, a ex-escrava do Tejuco foi registrada pejorativamente nas Memórias do Distrito Diamantino, de Joaquim Felício dos Santos, tio-avô de João Felício dos Santos, coroteirista da trama para a telona. Chico Rei apareceu no livro de Diogo Vasconcellos (1999) História Antiga de Minas, em 1904. Na poesia, Cecília Meireles (1965) dedicou cantos específicos 


\section{Crevisto}

aos protagonistas negros em seu Romanceiro da Inconfidência(1953). Em 1966, o romancista Agripa Vasconcelos lançou a coleção em seis volumes Saga do País das Gerais, dedicando um título para cada umdos referidos personagens. Por fim, a escola de samba carioca Acadêmicos do Salgueiro desenvolveu seu enredo carnavalesco a partir das histórias de Chica da Silva (1963) e de Chico Rei (1964), sagrando-se campeã e vice-campeã, respectivamente.

Apesar das coincidências, uma diferença entre essas narrativas chama atenção. A vida de Chica da Silva está documentada, sendo, por isso, considerada uma personagem histórica. Ao contrário de Chico Rei, inscrito na memória popular e encarado como lenda, tal qual referenciou Walter Lima Júnior no início do seu filme. Voltaremos a essa diferença, após abordamos a relação entre os filmes e os livros didáticos.

Conforme indicamos, os parâmetros de seleção foram estabelecidos considerando três recortes temporais: 1º) 1978-1985; 2) 1986-1996; 3) 19972006. Suprimimos da pesquisa títulos voltados para história geral e escolhemos um ano para referências com mais de uma edição. Considerando os novos filtros:

Tabela 1: Referência a Chica da Silva e Chico Rei em livros didáticos para o ensino fundamental e médio 1978-2006

\begin{tabular}{|c|c|c|c|c|c|c|c|c|c|c|c|c|}
\hline Período & $\begin{array}{c}\left.1^{\circ}\right) \\
78 / 8\end{array}$ & $\begin{array}{c}\left.1^{\circ}\right) \\
78 / 8\end{array}$ & $\begin{array}{c}\left.1^{\circ}\right) \\
\text { Tota }\end{array}$ & $\begin{array}{c}\left.2^{\circ}\right) \\
86 / 9\end{array}$ & $\begin{array}{c}\left.2^{\circ}\right) \\
86 / 9\end{array}$ & $\begin{array}{l}2^{\circ} \text { ) } \\
\text { Tota }\end{array}$ & $\begin{array}{c}\left.3^{\circ}\right) \\
97 / 0\end{array}$ & $\begin{array}{c}\left.3^{\circ}\right) \\
97 / 0\end{array}$ & $\begin{array}{c}\left.3^{\circ}\right) \\
\text { Total }\end{array}$ & $\begin{array}{l}\text { Subt } \\
\text { otal }\end{array}$ & $\begin{array}{c}\text { Subto } \\
\text { tal }\end{array}$ & Total \\
\hline $\begin{array}{c}\mathrm{F}=\text { Fundame } \\
\text { ntal } \\
\text { M=Médio }\end{array}$ & $\begin{array}{l}5 \\
F\end{array}$ & $\begin{array}{l}5 \\
M\end{array}$ & l & $\begin{array}{l}6 \\
F\end{array}$ & $\begin{array}{l}6 \\
M\end{array}$ & l & $\begin{array}{l}6 \\
F\end{array}$ & $\begin{array}{l}6 \\
M\end{array}$ & & $\mathrm{~F}$ & $M$ & \\
\hline Livros & 61 & 21 & 82 & 83 & 30 & 113 & 100 & 18 & 118 & 244 & 69 & 313 \\
\hline Referência & 3 & 6 & 9 & 11 & 10 & 21 & 20 & 4 & 24 & 34 & 20 & 54 \\
\hline Relação \% & 4.9 & 28.5 & 10.9 & 13.2 & 33.3 & 18.5 & 20 & 22 & 20.3 & 13.9 & 28.9 & 17.2 \\
\hline
\end{tabular}

Fonte: Acervo LIVRES - FE/USP 


\section{Gevisto
Observatório}

ISSN n² 2447-4266

Vol. 3, n. 2, Abril-Junho. 2017

DOI: http://dx.doi.org/10.20873/uft.2447-4266.2017v3n2p136

A relação de ocorrências de referências relativas aos personagens Chica da Silva e Chico Rei nos livros didáticos apresenta progressivo aumento (10.9\%, $18.2 \%$ e $20.3 \%$, respectivamente), com média de $17.2 \%$ para todo o recorte temporal. Uma primeira análise pode indicar baixo índice de menções dos filmes na totalidade dos livros. Porém, ressalvamos que os contextos da escravidão e da colonização, nos quais as tramas filmicas se desenvolvem, são específicos para um determinado ano da escolarização, enquanto o material selecionável compõe uma coleção didática voltada a todo ensino fundamental. Desse modo, esse índice em relação ao cômputo global tende a subir caso excluíssemos os demais volumes da coleção.

Proporcionalmente, o material voltado ao ensino médio ( $2^{\circ} \mathrm{grau}$ ) apresentou maior incidência: pouco mais que o dobro em relação ao ensino fundamental. Dentre os períodos, o mais recente se distinguiu quase equipararas ocorrências entre os níveis. $03^{\circ}$ período também se diferenciou por apresentar a maior taxa percentual de indicações para a faixa do ensino fundamental.

Considerando as recorrências de menções nos livros, estabelecemos algumas categorias, que por vezes se sobrepõem. Para Xica da Silva, definimos seis critérios: $1^{\circ}$ ) Filme - para referências diretas à película; $2^{\circ}$ ) Fonte - há menção às obras de referência sobre a protagonista; $3^{\circ}$ ) Diálogo com historiografia -à luzda produção historiográfica sobre Chica da Silva e seu contexto; $\left.4^{\circ}\right)$ Iconografia - remete a reprodução iconográfica sobre Chica da Silva e seu período; $5^{\circ}$ ) Extração de Diamantes - o contratador e o romance, considerando destaques tanto à economia diamantífera, quanto ao romance entre João Fernandes e a ex-escrava; $6^{\circ}$ ) Elementos de ostentação - que enfatiza o lado exótico da história, como riqueza, joias, mucamas, navio. 


\section{Rrevisto}

ISSN n० 2447-4266

Vol. 3, n. 2, Abril-Junho. 2017

DOI: http://dx.doi.org/10.20873/uft.2447-4266.2017v3n2p136

Tabela 2: Categorias temáticas referentes a Chica da Silva abordadas nos livros didáticos

\begin{tabular}{|c|c|c|c|c|c|c|}
\hline Período/tema & $\begin{array}{l}\text { Filme } \\
\text { Xica da } \\
\text { Silva }\end{array}$ & $\begin{array}{l}\text { Fonte } \\
\text { sobre } \\
\text { Chica da } \\
\text { Silva }\end{array}$ & $\begin{array}{c}\text { Diálogo } \\
\text { com a } \\
\text { historiografia }\end{array}$ & Iconografia & $\begin{array}{c}\text { Extração de } \\
\text { diamantes } \\
\text { contratador } \\
\text { e o romance }\end{array}$ & $\begin{array}{c}\text { Elementos } \\
\text { de ostentação de } \\
\text { Chica } \\
\text { (navio, } \\
\text { mucamas...) }\end{array}$ \\
\hline $\begin{array}{c}\left.1^{\circ}\right) 78 / 85 \\
\text { Fundamental }\end{array}$ & 1 & - & - & 2 & 2 & - \\
\hline $\begin{array}{c}\left.2^{\circ}\right) 86 / 96 \\
\text { Fundamental }\end{array}$ & - & 1 & 1 & 3 & 8 & 1 \\
\hline $\begin{array}{c}\left.2^{\circ}\right) 86-96 \\
\text { Médio }\end{array}$ & 1 & 1 & 5 & 2 & 5 & - \\
\hline Total & 17 & 10 & 11 & 11 & 33 & 5 \\
\hline
\end{tabular}

Fonte: Acervo LIVRES-FE/USP.

As mesmas categorias foram utilizadas para as análises referentes ao Chico Rei, com exceção do critério /conografia, por não ter sido constatado nenhum cruzamento nesse sentido;e dos critérios $5^{\circ}$ e $6^{\circ}$ por serem específicos da história de Chica da Silva.

Tabela 3: Categorias temáticas referentes a Chico Rei abordadas nos livros didáticos

\begin{tabular}{|c|c|c|c|}
\hline Período/tema & $\begin{array}{c}\text { Filme } \\
\text { Chico Rei }\end{array}$ & $\begin{array}{c}\text { Fontes } \\
\text { sobre } \\
\text { Chico Rei }\end{array}$ & $\begin{array}{c}\text { Diálogo } \\
\text { com a } \\
\text { historiografia }\end{array}$ \\
\hline $\begin{array}{c}\left.1^{\circ}\right) 78 / 85 \\
\text { Fundamental }\end{array}$ & - & - & - \\
\hline $\begin{array}{c}\left.1^{\circ}\right) 78 / 85 \\
\text { Médio }\end{array}$ & - & 1 & 1 \\
\hline $\begin{array}{c}\left.2^{\circ}\right) 86 / 96 \\
\text { Fundamental }\end{array}$ & 2 & - & 1 \\
\hline $\begin{array}{l}\left.2^{\circ}\right) 86-96 \\
\text { Médio }\end{array}$ & - & - & 4 \\
\hline $\begin{array}{c}\left.3^{\circ}\right) 97-06 \\
\text { Fundamental }\end{array}$ & 4 & - & 4 \\
\hline $\begin{array}{l}\left.3^{\circ}\right) \text { 97-06 } \\
\text { Médio }\end{array}$ & 1 & - & - \\
\hline Total & 7 & 1 & 10 \\
\hline
\end{tabular}

Revista Observatório, Palmas, v. 3, n. 2, p. 136-171, abr./jun. 2017 


\section{Gevisto
Observatório}

ISSN n² 2447-4266

Vol. 3, n. 2, Abril-Junho. 2017

DOI: http://dx.doi.org/10.20873/uft.2447-4266.2017v3n2p136

Atribuímos o maior diálogo entre os livros e o cinema no período final como decorrência da valorização entre os professores do uso do audiovisual em suas aulas. Por raciocínio inverso, confirmamos a expectativa de menor incidência para $\circ 1^{\circ}$ período, pois era incipiente a discussão do uso metodológico do filme para o aprendizado escolar durante a transição para a década de 1980, encontrando neste recorte a menor taxa de referências para o ensino fundamental.

Surpreendeu-nos, aqui, a menção a Xica da Silvano livro de Álvaro de Alencar, voltado a $5^{a}$ série (atual $6^{\circ}$ ano), de 1983 . O material reproduz um frame do filme, assim legendado: "Lavagem de diamantes, cena de Xica da Silva, filme que narra a vida de uma escrava liberta e seu romance com um alto funcionário da Intendência dos Diamantes" (ALENCAR, 1983:73).

No texto há preocupação em explicar a singularidade da extração diamantífera, que conferia exclusividade ao contratador, alijando a população local da riqueza. Pedagogicamente, a figura permite a visualização do modo de trabalho nas Minas setecentistas, estimulando a discussão sobre a exploração colonial e o escravismo. O romance do contratador com Chica da Silva também é abordado, com realce a conquista da liberdade pela ex-escrava. Destacamos, ainda, a equivocada identificação da função do contratador.

No caso de Xica da Silva, foi recorrente nas publicações apresentá-lo como contestação à condição de colônia, sendo a Demarcação Diamantina o exemplo maior dos abusos do Estado. Na chave da denúncia à violência do escravismo, aos castigos e às más condições de vida, recorre-se a iconografia reproduzida de Carlos Julião (século XVIII), Rugendas e Debret (século XIX).

Porém, percebemos nas novas edições a tendência em supervalorizar a relação privada entre o senhor e a ex-escrava e a extravagância com que Chica 


\section{Orevisto}

ISSN n² 2447-4266

Vol. 3, n. 2, Abril-Junho. 2017

DOI: http://dx.doi.org/10.20873/uft.2447-4266.2017v3n2p136

foi representada. Alguns livros apresentaram argumentos frágeis ao abordar o contexto sócio-histórico da protagonista:

Chica, quando ia à igreja coberta de tecidos de seda importada e de joias de ouro e de diamantes, fazia-se acompanhar de uma comitiva de 12 mulatas suntuosamente vestidas. Tanto luxo e ostentação deviam provocar o ódio das famílias brancas, profundamente racistas, cujo descontentamento se tornava maior porque à Chica da Silva estava reservado o lugar mais importante da igreja (AQUINO, 1991, p. 102).

Sobressai no excerto a canônica sequência fílmica em que a ex-escrava (interpretada por Zezé Motta)passeia pelas ruas do arraial a ostentar sua carta de alforria. Todavia, em seguida, o autor afirma justamente o contrário da continuidade da sequência dirigida por Diegues: o veto à entrada de Chica à igreja, permitida somente aos livres $e$ brancos; não apenas livres.

Comparada a Xica da Silva, a menor incidência de referências ao Chico Reinos livros didáticos parece ser explicada pelo aspecto pitoresco romance e o sucesso - não menos polêmico - do filme de Diegues, somado à peculiaridade da administração da região diamantina. Consideramos, ainda, a baixa circulação do filme de Walter Lima Jr. devido aos problemas de finalização, restringindo seu conhecimento pelo grande público.

O $2^{\circ}$ período parece confirmar o exotismo e polêmica como fatores para a maior inserção de Chica da Silva nas aulas de história, conforme sugere o aumento de referências inscritas no parâmetro analítico sobre sua vida e romance com o contratador.

Ainda no $2^{\circ}$ período, ao analisar a categoria historiografia, temos um índice percentual próximo: Chico Rei atinge 50\% e Xica da Silva 54.5\%. Podemos dizer que os autores recorrem ao exemplo de Chico Rei para fomentar uma discussão a respeito da escravidão, quilombo e alforria menos suscetível a 


\section{Crevisto}

ISSN n² 2447-4266

Vol. 3, n. 2, Abril-Junho. 2017

DOI: http://dx.doi.org/10.20873/uft.2447-4266.2017v3n2p136

polêmicas, como as decorrentes dos excessos das representações de Xica da Silva - identificáveis nas fontes literárias, mas potencializadas após a exibição do filme e da novela exibida pela TV Manchete, em 1996/97.

Ambos os personagens continuam a ser abordados no conteúdo referente à colonização, por vezes tensionando não só o filme,mas também a historiografia, como o caso da alforria negociada.No livro História: passado e presente, ao trabalhar a violência da escravidão, as autoras utilizam a iconografia (Debret), um excerto de lei setecentista e apresentam um box com a lenda de Chico Rei. Embora não citem especificamente o filme, a narrativa é bem imagética ao recuperar os elementos que explicam o processo de liberdade obtida pelo líder negro e como ele agiu para libertar os demais. Contudo, as autoras questionam a alforria em Minas, especialmente, entre os homens (CARMO; COUTO, 1997, p. 174), contrapondo-se a renovação historiográfica que apresentava novos dados e análises para estudos sobre o escravismo.

Enquanto referências às fontes nos livros didáticos se acentuam após a LDB/96, menções à historiografia ocorrem desde os anos 1980. Neste caso,a incidência foi mais comum no ensino médio e dentro do $2^{\circ}$ recorte temporal de análise. Situação invertidano $3^{\circ}$ período, quando predominam referências a historiografia nas publicações para o ensino fundamental. Levantamos duas hipóteses para esse cenário:1ª) a percepção de que leituras mais complexas, de viés acadêmico, são mais adequadas ao ensino médio; $2^{\mathrm{a}}$ ) aproxima a historiografia e a educação histórica, estabelecendo um ensino que problematiza conceitos e o processo histórico também nas faixas etárias mais novas. Observamos que a segunda hipótese não invalida a primeira, outrossim, assinala um movimento de renovações no campo da metodologia do ensino, 


\title{
Crevisto
}

ISSN n² 2447-4266

Vol. 3, n. 2, Abril-Junho. 2017

DOI: http://dx.doi.org/10.20873/uft.2447-4266.2017v3n2p136

expressos na documentação reguladora para a educação após 1996 (LDB e PCNs).

Nesse sentido, destacam-se alguns temas, como a problematização das fontes literárias e cinematográficas para os anacronismos na representação de Chica da Silva. Ouo questionamento da alforria como tática de luta pela liberdade, com alguns autores considerando o aquilombamento a única maneira de se tornar realmente livre.

Em ambos os períodos, a menção aos filmes funciona como estímulo a reflexão com a historiografia. Um exemplo desta preocupação encontra-se no livro História da sociedade brasileira $\left(2^{\circ} \mathrm{grau}\right)$, inscrito no $1^{\circ}$ período de análise. Na seção "Guia do Professor" a orientação passa pela crítica à condição de colônia e ao racismo como herança do escravismo. Os argumentos são reforçados por indicações de leitura para aprofundamento do tema: Charles Boxer e a coleção História Geral da Civilização Brasileira, organizada por Sérgio Buarque de Holanda. Na parte voltada ao aluno, destaca-se a opressão ao trabalho escravo e a resistência.

\begin{abstract}
A presença negra na civilização que nascia nas Gerais aparece em tipos lendários como Chica da Silva, a "Chica que Manda", e Chico Rei, o negro liberto que comprava cartas de alforria para seus irmãos de cor. Mas segregação continua: surgem igrejas e irmandades religiosas só para pretos. (ALENCAR, 1985, p. 20)
\end{abstract}

A produção de materiais didáticos procurou absorver as políticas educacionais e orientações pedagógicas da década de 1990. Os livros traziam, ainda, a reflexão das novas gerações de historiadores e renovadas práticas de ensino, que valorizavam fontes e recursos como o audiovisual. Revelando esse impacto, constatamos expressivo aumento de referências aos filmes Xica da 


\section{Qrevisto}

ISSN n² 2447-4266

Vol. 3, n. 2, Abril-Junho. 2017

DOI: http://dx.doi.org/10.20873/uft.2447-4266.2017v3n2p136

Silva e Chico Rei a partir de 1996 - período que concentra menções nos livros didáticos.

Alguns livros reservaram seções, às vezes demarcadas por ícones apropriados, para sugerir filmes ligados ao conteúdo; à semelhança da recomendação bibliográfica complementar. Contudo, nem sempre as indicações parecem adequadas à faixa etária ${ }^{10}$.

A apresentação do filme também requer mais cuidado em sua produção(editoras e autores). A exibição fílmica com fins educativos requer um plano de trabalho que oriente o aluno a atingir a finalidade daquela atividade (Napolitano, 2008). Acreditamos que o bom plano se inicia com informações claras do que será exibido, o que implica uma sinopse mais completa do que a proposta pela distribuição comercial. Contudo, não é isso que predominou - às vezes, nem mesmo a sinopse acompanha o título fílmico (PANAZZO; VAZ, 2005, p. 80).

É conhecida a crítica que o cinema-história recebe pela liberdade poética e pelos possíveis equívocos decorrentes de suas representações (realismo $\mathrm{x}$ subjetivismo). No caso de Xica da Silva, a direção caricatural com tons carnavalescos o contrapõe a densidade dramática de Chico Rei. Isto favorece uma inversão na percepção pelo espectador da inscrição desses personagens no processo histórico. Apesar da documentação referente a Chica da Silva e o imaginário construtor da lenda de Chico Rei, não é incomum que o filme de

${ }^{10}$ O livro Brasil: uma história em construção (Macedo, 1996), por exemplo, sugere os filmes Chico Rei, Ganga Zumba e Quilombo (Cacá Diegues, 1964; 1984) para o tema do escravismo. Contudo, indica aos alunos do ensino fundamental leituras densas e comuns na graduação em História, como Eugene Genovese e Thomas Skidmore. Para a temática da mulher, os filmes apresentados também são questionáveis à faixaetária: Mulher índia (Eliane Bandeira, 1985), $A$ cor púrpura (Steven Spilberg, 1985), Inocência (Walter Lima Jr., 1983), além de Xica da Silva; (MACEDO, 1996:102; 127). 


\section{Orevisto}

ISSN n² 2447-4266

Vol. 3, n. 2, Abril-Junho. 2017

DOI: http://dx.doi.org/10.20873/uft.2447-4266.2017v3n2p136

Cacá Diegues seja considerado menos História se comparado ao realizado por Walter Lima Jr.

$\mathrm{Na}$ educação escolar, o peso da crítica polarizada no realismo $\mathrm{x}$ subjetivismo é assaz acentuado. Ainda assim, resistências foram superadas.A produção editorial e os professores consideram, cada vez mais, a pertinência do uso metodológico do filme. Destacamos o papel articulador do cinema para a circularidade do conhecimento histórico, já que retoma, em sua produção, narrativas e saberes sobre o tema e reelabora narrativas que estimulam 0 debate e o aprendizado, tanto no âmbito escolar, quanto fora dele. O uso dos filmes na educação favorece a problematização das interpretações históricas.

\section{Considerações}

"Eu fazia história pública e não sabia" revela o reconhecimento da sala de aula como espaço propício para o seu desenvolvimento enquanto prática profissional, sobremaneira por proporcionar: ampliação do público, divulgação do saber, colaboração/compartilhamento e circularidade do conhecimento. Compreendendo o processo de ensino-aprendizagem como mediação didática, narrativas e suportes variados estabelecem diálogos para a significação da História, considerando suas dimensões de passado e de presente.

A proximidade entre educação e história pública se acentua na interface com o cinema-história. O filme com temática histórica se revela importante prática de ampliação e divulgação do público ao mobilizar diversos suportes para produzir uma narrativa cinematográfica da História, ressignificando aquele saber circulante.

Para pensar o uso do filme na educação escolar, analisamos a inserção das narrativas fílmicas nos livros didáticos, que talvez seja o maior divulgador 


\section{Oevisto}

ISSN n² 2447-4266

Vol. 3, n. 2, Abril-Junho. 2017

DOI: http://dx.doi.org/10.20873/uft.2447-4266.2017v3n2p136

do conhecimento histórico, haja vista seu extensivo papel na formação geracional. Apesar da centralidade deste material na educação, seu uso requer cuidados, pois é um manual educativo inscrito entre interesses políticos e econômicos. Não obstante, é possível trabalhar com ele por meio de análises críticas que permitam perceber processos de construção de memórias e suas representações.

Os filmes Xica da Silva (1976) e Chico Rei (1985) foram tomados como referência para identificar a linguagem fílmica como procedimento didático. Consultamos livros didáticos entre 1978 e 2006, contemplando a chegada da discussão às escolas, seu acolhimento e a adequação às novas diretrizes educacionais (LDB/96). Referências aos filmes nos livros didáticos se intensificam a partir de meados da década de 1980, como reflexo da popularização da tecnologia, das políticas educacionais e da renovação das pesquisas e práticas de ensino.

As semelhanças da construção narrativa de Xica da Silva e Chico Rei e o mesmo contexto histórico no qual são ambientados permitiram chaves analíticas para dimensionarmos o diálogo entre filme e livro didático. Nesse sentido,a historiografia foi bastante mobilizada, mas nem sempre houve concordância do autor com as novas pesquisas.

Percebemos, também, a influência do filme sobre o autor. O lado extravagante de Xica da Silva,por exemplo, passou a predominar sobre as indicações relacionadas ao conteúdo. Por outro lado, a narrativa dramática de Chico Rei estimulava debates com a historiografia.

Os livros mais recentes incorporaram os recursos audiovisuais para o ensino da disciplina. Contudo, muitos ainda abordam o filme na dicotomia realismo $x$ subjetividade. Ou, então, parecem cumprir uma obrigação editorial, 


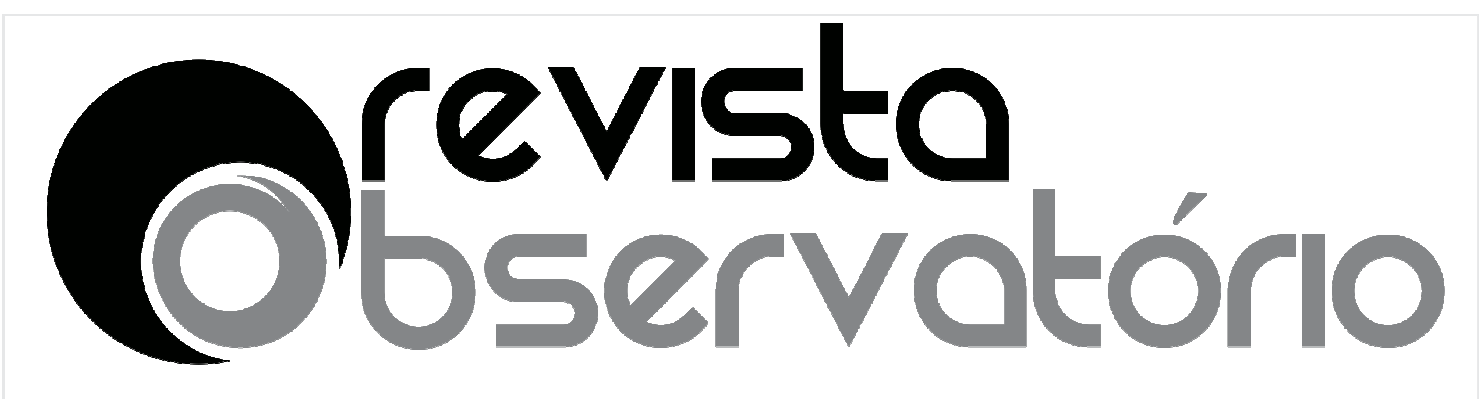

ISSN n² 2447-4266

Vol. 3, n. 2, Abril-Junho. 2017

DOI: http://dx.doi.org/10.20873/uft.2447-4266.2017v3n2p136

sem aprofundar as possibilidades da narrativa fílmica para a construção do conhecimento histórico.

\begin{abstract}
Apesar de ser uma arte centenária e muitas vezes ao longo da história ter sido pensado como linguagem educativa, o cinema ainda tem alguns problemas para entrar na escola. (...) A maioria das experiências relatadas ainda se prende ao conteúdo das histórias, às fabulas em si, e não discute outros aspectos que compreendem a experiência do cinema. (NAPOLITANO, 2008, p. 7)
\end{abstract}

Significar historicamente um filme na sala de aula é um processo que não considera, apenas, o conhecimento histórico circulante. Deve levar em conta, também, a operação do pensamento histórico desenvolvido intelectualmente no cotidiano escolar e na produção de pesquisas acadêmicas. É um processo de educação do olhar, que deve ultrapassar os limites do conteúdo formal e incentivar questões suscitadas também pelo filme.

\title{
Livros Didáticos
}

ALENCAR, Álvaro Duarte. História do Brasil: evolução econômica, política e social (5a série). 5.ed. SP: Saraiva, 1983.

ALENCAR, Francisco; et.al. História da sociedade brasileira ( $2^{\circ}$ grau). 3.ed. 1985.

AQUINO, Rubim; et.al. Fazendo a história: as sociedades americanas e a Europa na época moderna. 3.ed. SP: Editora do Livro Técnico, 1991.

CARMO, Sonia Irene S. do; COUTO, Eliane. História passado presente: Brasil colônia (1º grau). 2.ed. SP: Atual, 1997.

MACEDO, José Rivair. Brasil: uma história em construção. SP: Editora do Brasil, 1996. 


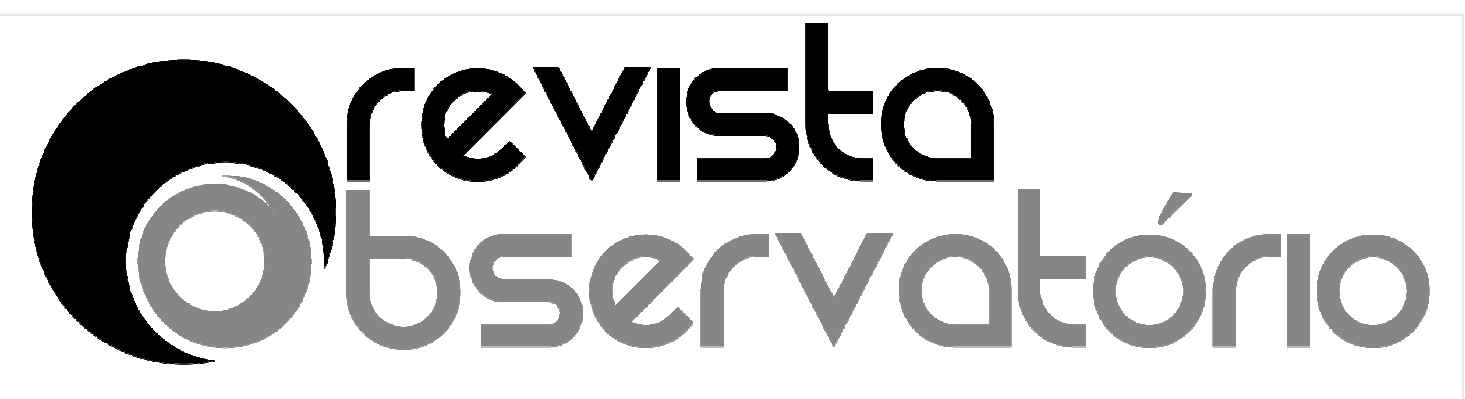

ISSN n² 2447-4266

Vol. 3, n. 2, Abril-Junho. 2017

DOI: http://dx.doi.org/10.20873/uft.2447-4266.2017v3n2p136

PANAZZO, Silvia; VAZ, Maria Luísa. Navegando pela História (7a série). SP: Quinteto Editorial, 2005.

VICENTINO, Cláudio. Viver a História: 6ª série. SP: Scipione, 2002.

\section{Referências}

ALMEIDA, Joaquim C.M. de. Cinema contra cinema: bases para um esboço de organização do cinema educativo no Brasil. SP: Ed. Nacional, 1931.

ALMEIDA, Juniele; MAUAD, Ana; SANTHIAGO, Ricardo. (Org.). História Pública no Brasil: sentidos e itinerários. SP: Letra e Voz, 2016.

ALMEIDA, Juniele; ROVAI, Marta (Org). Introdução à história pública. SP: Letra e voz, 2011.

ANDRADE, Everardo; ANDRADE, Nívea. Tecendo uma conversa, experimentando uma textura. In: ALMEIDA, Juniele; MAUAD, Ana; SANTHIAGO, Ricardo. (Org.). História Pública no Brasil: sentidos e itinerários. SP: Letra e Voz, 2016.

BITTENCOURT, Circe M.F. Livro didático e conhecimento histórico: uma história do saber escolar. Tese. FFLCH/USP, Universidade de São Paulo, 1993.

CHERVEL, André. História das disciplinas escolares: Reflexões sobre um campo de pesquisa. Teoria e Educação, n 2, Porto Alegre: Pannônica, 1990, p. 177-229.

CHEVALLARD, Yves. La transposición didáctica. Del saber sábio al saber enseñado. Buenos Aires: Aique Grupo Editor, 1995.

CHOPPIN, Alain. História dos livros e das edições didáticas: sobre o estado da arte. Revista Educação e Pesquisa, v.30, n.3, São Paulo, set./dez.2004, p.549566. 


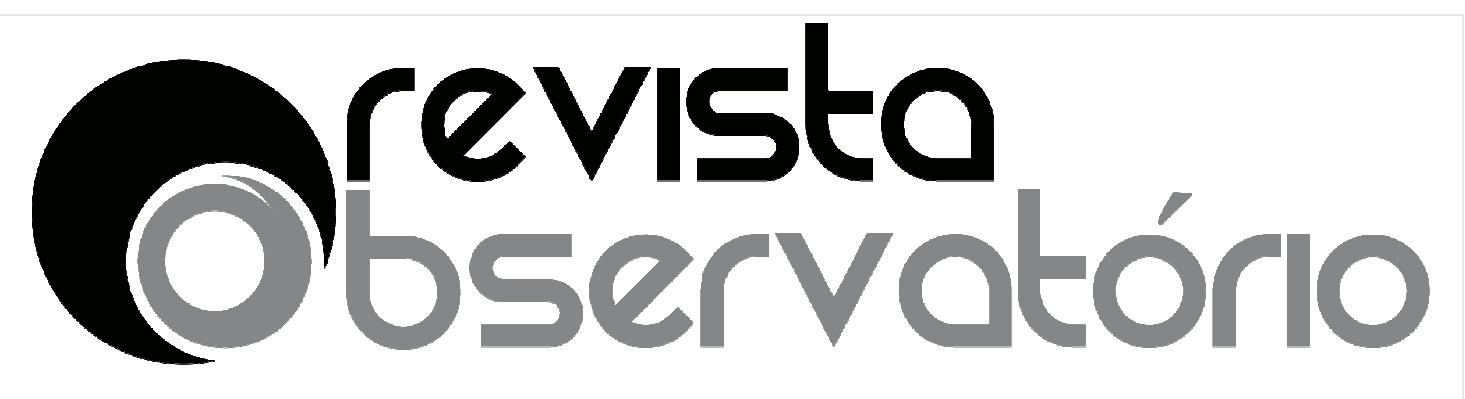

ISSN n² 2447-4266

Vol. 3, n. 2, Abril-Junho. 2017

DOI: http://dx.doi.org/10.20873/uft.2447-4266.2017v3n2p136

FERREIRA, Rodrigo de Almeida. Cinema, História Pública e Educação: circularidade do conhecimento histórico em Xica da Silva (1976) e Chico Rei (1985). Tese. UFMG, Belo Horizonte, 2014.

FONSECA, Thaís N.L. e. Ensino de História, mídia e história pública. In: ALMEIDA, Juniele; MAUAD, Ana; SANTHIAGO, Ricardo. (Org.). História Pública no Brasil: sentidos e itinerários. SP: Letra e Voz, 2016.

FREIRE, Paulo. Pedagogia do oprimido. 9.ed. RJ: Paz e Terra, 1981.

GASPARELLO, Arlete M.Construtores de identidade. SP: Iglu, 2004.

LERA, José Maria Caparrós. Guia del espectador de cine. Madrid:Alianza Editorial, 2007.

LIDDINGTON, Jill. O que é história pública? Os públicos e seus passados. In.: ALMEIDA, Juniele; ROVAI, Marta. (Org). Introdução à história pública.SP: Letra e voz, 2011.

LUCKESI, Cipriano. Avaliação da aprendizagem na escola: reelaborando conceitos e recriando a prática. Salvador: Malabares Comunicação e Eventos, 2003.

MONTEIRO, Ana Maria. Formação de professores: entre demandas e projetos. Revista História Hoje, v.2, n.3, São Paulo,USP, jun.2013, p.19-42.

MORETTIN, Eduardo. Cinema educativo: uma abordagem histórica. Revista Comunicação e Educação, n.4, São Paulo, set./dez.1995, p.13-19.

MORETTIN, Eduardo. Humberto Mauro, cinema, história. SP: Alameda, 2013.

MUNAKATA, Kazumi. O livro: alguns temas de pesquisa. Revista Brasileira de História da Educação, v.12, n.3, Campinas, p.179-197, set./dez. 2012. 


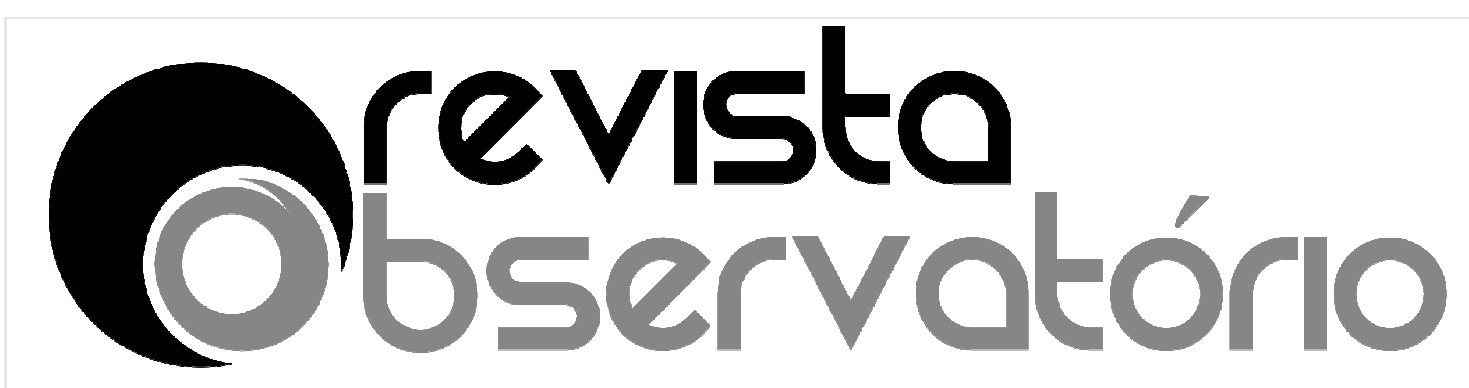

ISSN n² 2447-4266

Vol. 3, n. 2, Abril-Junho. 2017

DOI: http://dx.doi.org/10.20873/uft.2447-4266.2017v3n2p136

NAPOLITANO, Marcos. Como usar o cinema na sala de aula.4.ed. SP: Contexto, 2008.

NAPOLITANO, Marcos. Fontes audiovisuais: a história depois do papel. In.: PINSKY, Carla; LUCA, Tânia de. (Orgs). Fontes históricas. SP: Contexto, 2005.

ROSA, Cristina S. da. O cinema educativo através dos discursos de Mussolini e Vargas. Mnemocine, Campinas, 2008.

SÁ, Irene T. de. Cinema e educação. RJ: Agir, 1967.

SANTHIAGO, Ricardo. Duas palavras, muitos significados: alguns comentários sobre a história pública no Brasil. In: ALMEIDA, Juniele; MAUAD, Ana; SANTHIAGO, Ricardo. (Org.). História Pública no Brasil: sentidos e itinerários. SP: Letra e Voz, 2016.

SERRANO, Jonathas; VENÂNCIO Fo, Francisco. Cinema e educação. SP: Melhoramentos, 1931.

SIMIS, Anita. Estado e cinema no Brasil. SP: UNESP, 2015. 